\title{
Performative kunstdidaktiske erfaringer som praksisrefleksjon
}

\author{
Stine N. Ellinggard ${ }^{1} \&$ Karin B. Bjerkestrand ${ }^{2}$ \\ ${ }^{1}$ OsloMet - storbyuniversitetet, Norge; ${ }^{2}$ Universitetet $i$ Stavanger, Norge
}

\begin{abstract}
Abstrakt
Hensikten med denne studien er å undersøke hva performative kunstdidaktiske erfaringer kan tilføre praksisrefleksjonen til PPU (praktisk pedagogisk utdanning) studenter i drama og teater. Forfatterne har gjennomført tre performative kunstdidaktiske forløp med studenter fra to PPUutdanninger i drama og teater i Norge. I etterkant av hvert forløp har forfatterne hatt gruppeintervju, hvor studentene delte sine opplevelser knyttet til refleksjoner over det å utvikle lærerrollen. I denne artikkelen diskuterer vi betydningen av dramafagets kunstdidaktiske muligheter i refleksjon over praksis. Gjennom analyse av studentenes utsagn, utkrystalliserte det seg tre perspektiver: kroppens minne, gjenkjennelsesfelleskapet og distanseperspektivet. Disse perspektivene tilfører, ifølge studentene, et utvidet refleksjonsrom, noe den mer tradisjonelle praksisrefleksjonen ikke rommer.
\end{abstract}

Emneord: dramapedagogikk; lererrollen; performativ kunstdidaktikk; praksisrefleksjon

\begin{abstract}
Performative didactic as practice reflection

The purpose of this study is to investigate what performative didactics can add to practice reflection for students in practical pedagogical drama education (PPU). The authors have completed performative didactic drama and theatre processes with students from two PPU educations in drama and theatre in Norway. Each drama and theatre process ended with qualitative group interviews. The students shared their experiences and reflections related to the skills of the teacher role. In this article, we discuss the possibilities of drama and theatre as a form of reflection. Through the analysis of the students' statements, three perspectives emerged; the memory of the body, the collective recognition and the perspective of distance. According to the students, these perspectives added an expanded space for reflection, which the more traditional practice reflection does not contain.
\end{abstract}

Keywords: drama education; performative didactics; practice reflection; the role of the teacher

Received: June, 2020; Accepted: June, 2021; Published: September, 2021

\section{Innledning}

Som lærere i drama og teater på PPU (praktisk pedagogisk utdanning), er forfatterne av denne artikkelen engasjert i utviklingen av lærerrollen i et utdanningsløp. Undersøkelsen er basert på PPU-studenters praksisperiode i grunnskolen, og er en 
kvalitativ studie som undersøker studentenes estetiske erkjennelsesprosesser som refleksjon over praksis. Vi fordyper oss i en performativ kunstdidaktikk som kan bidra til meningsskaping, noe som innebærer «komplekse, kroppslige, kognitive, relasjonelle og affektive prosesser som foregår hele tiden, og som inngår i og er en forutsetning for både læring og undervisning» (Østern et al., 2019, s. 24). Samfunnet er i rask endring. I opptakten til fagfornyelsen våren 2020 ble alle Norges skoler stengt ned som en følge av covid-19. Mange lærere deltok i den digitale dugnaden og utviklet nye undervisningsformer. Fremtidens skole trenger lærere som evner å utvikle seg, har relasjonell kompetanse og som kan skape trygge læringsmiljø. Lærerrollen er sammensatt. I gjeldende rammeplan for PPU-utdanning vedtatt i 2015 står det at studenten etter endt utdanning i PPU skal ha kunnskaper som innebærer bred forståelse for skolens mandat, opplæringens verdigrunnlag og opplæringsløpet (Forskrift om rammeplan for PPU, 2015). Videre skal studenten ha ferdigheter i å skape motiverende og inkluderende læringsmiljø og å lede og legge til rette for undervisningsforløp som fører til gode faglige og sosiale læringsprosesser. Studenten skal også ha generell kompetanse i å bygge relasjoner til elever og foresatte. Hvordan kan vi ivareta mangfoldet av kompetanser som framtidens skole fordrer i utdanningen av nye drama- og teaterlærere? I løpet av PPU-utdanningen er studentene minst 60 dager i praksis i grunnskole, videregående skole og/eller ulike kulturskoler og folkehøyskoler. Etter hver praksisperiode er refleksjonen over praksis vektlagt i studiet i form av samtaler, muntlige presentasjoner og skriftlige refleksjonsoppgaver. Vi ønsker gjennom denne artikkelen å undersøke og diskutere: Hva kan performative kunstdidaktiske erfaringer tilføre praksisrefleksjonen til PPU-studenter i drama og teater?

\section{Vitenskapsteoretisk ståsted og forskningsmetodikk}

Vi forholder oss til dramafagets epistemologiske historiske røtter gjennom John Dewey's erfaringsbaserte og sosialkonstruktivistiske kunnskapssyn knyttet til den estetiske erfaringen (Rasmussen, 2013, s. 27). Samtidig fokuserer vi på fagets utviklingspotensiale i et skjæringspunkt mellom kunst, didaktikk og samfunn. Professor Venke Aure kobler dette til en didaktikk på kunstens premisser (Aure, 2013). Denne strategien knyttes til en relasjonell og performativ kunstdidaktikk, som handler om å «koble an til kunstens premisser som grunnlag for didaktisk refleksjon» (Aure, 2013, s. 3). Forskningsmetodikken vi anvender baserer seg på en performativ kunstdidaktikk som inngang til kvalitative forskningsintervju med påfølgende analyse og fortolkning.

\section{Performativ kunstdidaktisk inngang}

Prosjektet ble gjennomført med 20 PPU-studenter ved to ulike studieinstitusjoner. Vi gjennomførte kunstdidaktiske undervisningsforløp, som innebærer en estetisk tilnærming til læring og refleksjon. Den performative kunstdidaktikken ble en del av praksisrefleksjon og kunnskapsgenerering etter at studentene hadde hatt en lengre 


\section{S. N. Ellinggard E K. B. Bjerkestrand}

praksisperiode i grunnskolen. «Å gå performativt til verks handler om hele tiden å være bevisst på og tillate formskapende aktiviteter i ulike uttrykksformer og formspråk» (Østern et al., 2019, s. 36). Spørsmålene vi stilte i forkant av de kunstdidaktiske forløpene, kan beskrives som undringsspørsmål som kunne åpne opp for «divergent tenkning, kreativ utprøving og ulike mulige svar og uttrykk» (Østern et al., 2019, s. 67). Vi søkte med denne tilnærmingen å trenge dypere inn i enkelte erfaringer, tanker og temaer som kunne være viktige for studentene å reflektere over etter endt praksis.

\section{Performativ kunstdidaktisk praksisrefleksjon}

Vi gjennomførte tre ulike kunstdidaktiske forløp ved begge PPU-studiestedene. Forløpene hadde til hensikt å utforske studentenes praksiserfaring gjennom en estetisk tilnærming basert på drama og teatermetoder. De ble utviklet i tett samarbeid mellom artikkelforfatterne. Bakgrunn for valg av arbeidsmetoder bunnet i et ønske om å ta utgangspunkt i kropp, følelser og intellekt som fortolkningsverktøy i praksisrefleksjonen. For å danne et bilde av det praktiske arbeidet følger en kort forklaring av de tre forløpene med eksempler på undringsspørsmål.

\section{Kunstdidaktisk forløp 1}

«Fra praksiserfaring til bevegelses presentasjon»

Undringsspørsmål: Hvilke bevegelser kan symbolisere noen av dine praksiserfaringer?

Studentene arbeider først individuelt med bevegelsesimprovisasjon basert på praksiserfaringene de har gjort seg. De utforsker ulike bevegelser som kan uttrykke noen av praksisopplevelsene. Etter en stund velger hver enkelt ut bevegelser som representer viktige erfaringer. Disse blir gjenskapt og delt i par. Sammen lager parene en enkel koreografi basert på felles og individuelle bevegelser. Arbeidet ender med at alle parene viser bevegelsessekvensene for hele gruppen etterfulgt av en kollektiv refleksjon.

\section{Kunstdidaktisk forløp 2}

«Fra praksiserfaring til fortelling i rolle med bevegelsesimprovisasjon»

Undringsspørsmål: Hva var din største og viktigste erfaring i praksis?

Studentene forteller i par om en praksiserfaring som har gjort ekstra inntrykk. Partner lytter, lever seg inn i og gir respons på fortellingen. Parene danner mindre grupper og studentene forteller hverandres fortellinger i rolle som "den andre» og resten av gruppen improviser bevegelser til fortellingen. Bevegelsene blir symbolske uttrykk for stemning, følelser, reaksjoner og opplevelser i fortellingen. Studenten som eier fortellingen, er publikum. Alle er publikum til en iscenesettelse av sin egen praksisfortelling. Det hele avsluttes med en kollektiv refleksjon. 


\section{Kunstdidaktisk forløp 3}

«Fra praksiserfaring til bevegelsesimprovisasjon»

Undringsspørsmål 1: Tenk deg at sålene til føttene dine har rød maling og du maler gulvet. Lag ulike mønstre. Jobb hele tiden med å skifte kombinasjoner av ulike mønstre. Tenk på en praksiserfaring som har gjort ekstra inntrykk på deg. Hvordan ser denne erfaringen ut i et gulvmønster?

Undringsspørsmål 2: Gå rundt i rommet for deg selv. Prøv å forestille deg praksisperioden og utforsk den med fokus på uttrykkspunktet tempo. Legg inn start og stopp hvis det er naturlig. Hvordan ser praksisreisen ut fra start til slutt med fokus på tempo?

Studentene arbeider fysisk med sine praksisfortellinger og -erfaringer gjennom oppgaver knyttet til bevegelsesimprovisasjon inspirert av viewpoints/uttrykkspunkt (vår oversettelse). Viewpoints er et system for bevegelskomposisjon hvor studentene i denne sammenheng utforsket sine praksiserfaringer knyttet til uttrykkspunktene tempo, varighet, kroppslig respons, repetisjon, form, gester, arkitektur, romlig relasjon og topografi (Bogart \& Landau, 2005). Studentene jobber individuelt med instruksjonsbeskjeder fra lærer og har påfølgende visninger med refleksjon for hverandre.

\section{Fokusgruppeintervju}

I etterkant av hvert undervisningsforløp hadde vi fokusgruppeintervju, som «kjennetegnes av en ikke-styrende intervjustil, der det først og fremst er viktig å få frem mange forskjellige synspunkter om emnet som er i fokus for gruppen» (Kvale, 2015, s. 179). Hvert av gruppeintervjuene hadde en varighet på en time hvor fokus var på PPU-studentenes opplevelser av det kunstdidaktiske arbeidet som grunnlag for deres egen praksisrefleksion. Vi tok lydopptak av intervjuene og transkriberte dem i etterkant. Vi hadde dermed mulighet for å veksle mellom å lytte til opptakene og lese transkripsionene, noe som åpnet for å ivareta både den muntlige og den skriftliggiorte siden av fokusgruppeintervjuene (Kvale, 2015, s. 218). Transkripsionene og opptakene dannet grunnlaget for en temabasert analyse, inspirert av Braun og Clarks (2006) seks faser innenfor tematisk analyse. Tematisk analyse er en metode for å identifisere, analysere og rapportere tema i datamateriale fra forskningsintervju (Braun \& Clark, 2006, s. 79). Fasene går fra det å bli kjent med datamaterialet til kategorisering, koding, lete etter, definere og navngi tema og til slutt formidling av resultatene (Braun \& Clark, 2006).

\section{Forskningsetikk}

Prosjektet er godkjent av NSD. Lydopptak ble slettet etter at de tre temaene var identifisert og aktuelle studentutsagn var valgt ut til forskningsformidlingen. Samtlige studenter på begge studiesteder gav samtykke til å delta etter at de hadde fått informasjon om forskningsprosjektet og at deltakelse var frivillig. Informantene er anonymisert gjennom 


\section{S. N. Ellinggard $\mathcal{G}$ K. B. Bjerkestrand}

bruk av nummer når de siteres $\mathrm{i}$ teksten. Som forskere samarbeidet vi tett gjennom utforming av alle sider ved prosjektet, og vi gjorde etiske refleksjoner og overveielser underveis. Dette bidro til bevissthet om vår forforståelse og fordommer (Gadamer, 2010), samt våre dobbelte roller som forskere og lærere. I lærerrollen ledet vi det performative kunstdidaktiske arbeidet, og i forskerrollen ledet vi fokusgruppeintervjuene. Dette definerte vi tydelig overfor studentene. Etter at vi hadde gjennomført det kunstdidaktiske arbeidet med påfølgende intervjuer, hadde vi, i rollen som forskende lærere, refleksjonssamtaler med hverandre. Vi fikk dermed en tidsavstand som hjalp oss til å reflektere, være kritiske og forhåpentligvis «skille mellom sanne fordommer som skaper forståelse og falske fordommer som skaper misforståelse» (Gadamer, 2010, s. 337).

\section{Spille noe til skue og skue spillet}

Dramafagets didaktikk bygger på estetiske erkjennelsesprosesser og kan knyttes til aristotelisk kunnskapstradisjon, som innebærer fire likeverdige former for kunnskap: episteme, techne, fronesis og arete. Episteme beskrives som den vitenskapelige, skriftbaserte og boklige kunnskapen, mens techne handler om den håndverksmessige kunnskapen, fronesis om sanselig kunnskap og arete er knyttet til dyd, gode egenskaper og klokskap (Aristoteles, 1999). Kunstfaget drama har sin opprinnelse i teaterkunsten og i leken. Dramafaget inneholder ulike former for virksomheter: uttrykksmessig, kommunikativ, opplevelsesmessig, analytisk og formmessig virksomhet. Disse utgiør en helhet av erfaringsmessige, ferdighetsmessige og sosiale aspekter (Haugsted, 1996a, s. 10-11). Dramafaget skiller seg spesielt ut fra andre kunstfag ved at virksomheten foregår ved hjelp av innlevelse og fantasi for å skape fiksjon. Det handler om en aktiv identifisering som krever både mental, fysisk og emosjonell innlevelse i forhold til roller, situasjoner, gjenstander og objekter (Sæbø, 2016, s. 24-25).

Kjernen i faget drama er agering, som kan gi mulighet for opplevelse og erkjennelse gjennom både virkelighetens rom - deltakerne og deres bevissthet om denne virkeligheten og det fiktive rom - de fiktive figurer og det fiktive forløp. Deltagerne i kunstdidaktiske forløp inntar en dobbeltrolle hvor de både spiller noe til skue og skuer spillet. «Adskillelsen mellom tilskuere og skuespillere er oppgitt, men på en sånn måte at vi stadig kan skille mellom fiksjon og virkelighet» (Szatkowski, 1996, s. 24).

Mennesket er uttrykksmiddelet i drama, noe som innebærer at tanker, følelser og handlinger aktiveres i utforskings-, lærings- og refleksjonsprosessen. Gjennom performative kunstdidaktiske erfaringer kan hele mennesket aktiveres. Det åpnes opp for en estetisk erfaring som kan innebære bevisstgjøring, utvikling og læring basert på egne erfaringer, refleksjoner, følelser og muligheter

\section{Den estetiske erfaring i performativ kunstdidaktikk}

Med utgangspunkt i den estetiske erfaringen som erkjennelsesform, kan vi oppdage andre momenter ved en refleksjon enn ved kun en kognitiv tilnærming (Dewey, 1934). 
I antologien Teater som danning (2013) belyser redaktørene hvordan vi som forskere innenfor ulike dramapraksiser ofte henviser til Deweys tenkning for å beskrive en dramaprosess:

Et sentralt tema er estetisk virksomhet betraktet som en egen opplevelsesmåte eller læringsmåte - den estetiske erfaring. [...] I tråd med dette karakteriseres den estetiske erfaring som en form for handlingskunnskap, i form av produksjon, resepsjon/ persepsjon og respons. (Heggstad et al., 2013, s. 14)

Den estetiske erfaringen kan føre til at vi oppdager noe nytt i en refleksjon, gjennom for eksempel gjenkjennelse (anagnorisis) i fiksjon, som aktør eller som tilskuer. Når Aristoteles beskriver fabelen i tragedien, fører det at vi gjenkjenner noe til omslaget fra uvitenhet til viten (Aristoteles, 1997, s. 46). Den estetiske erfaringsprosessen kan knyttes til Deweys beskrivelser om organiseringsprosessen av sterke erfaringer hvor «Den følelsesmessige fasen knytter delene sammen til en helhet; 'intellektuell' betegner ikke annet enn det faktum at erfaringen har mening; praktisk indikerer at organismen samhandler med de hendelsene og objektene som omgir den" (Dewey, 1934, s. 211). Ifølge Aure (2013) kan en relasjonell og performativ kunstdidaktikk «legge til rette for at lærestoffet kan bearbeides og fremstilles mer flersidig, dynamisk og spenningsfylt enn det mer endimensjonale modeller for formidling tilbyr» (Aure, 2013, s. 15).

Drama og teater som estetisk erfaring rommer et metodisk univers som ivaretar så vel utforsking gjennom ulike teaterkonvensjoner som teater $i$ form av at deltakerne spiller for hverandre. I den performative kunstdidaktiske prosessen veksler deltakerne mellom å være skuespillere og publikum. Den tyske teaterviteren Erika Fisher-Lichte er opptatt av teaterkunsten som en levende, fysisk, estetisk og imaginær sosial hendelse som hun kaller en autopoietisk feedbacksløyfe (vår oversettelse Fisher-Lichte, 2008, s. 39). Feedbacksløyfen kan forstås som en dynamikk i teaterhendelsen som involverer alle, både tilskuere og aktører. Dette kan påvirke og endre deltakerne gjennom det som Fisher-Lichte kaller en performativ estetikk.

I antologien Performative Approaches in Arts Education (2019) anvender redaktørene Østern og Knudsen tre argumenter for hva performative tilnærminger i utdanning kan være. Det første innebærer blant annet at det performative er åpent og mangfoldig i henhold til metoder, tema og personer. Det andre argumentet fremhever det performative som interdisiplinært og interkulturelt "and (we hope) interesting» (Østern \& Knudsen, 2019, s. 1). Til slutt argumenteres det for at det performative kan være en metode for å analysere og forstå verden (Østern \& Knutsen, 2019, s. 1). Østern et al. anvender begrepet performativ læring som relasjonell, kroppslig, affektiv, skapende og kognitiv (Østern et al., 2019, s. 57), noe som kan bidra til refleksjon både innefra og utenfra.

\section{Innenfra og utenfra}

Ved å forstå studentenes refleksjonsprosess både som en intellektuell og kroppslig prosess kan begrepet mentalisering anvendes. Mentalisering handler om «evnen til 


\section{S. N. Ellinggard $\mathcal{G}$ K. B. Bjerkestrand}

å gi mening til egen og andres atferd i lys av indre motivasjon, som følelser, tanker, lyster og behov; eller ofte forenklet til å se andre innenfra og seg selv utenfra (Fonagy et al., 2002, referert i Skårderud \& Duesund, 2014, s. 153). I dramafaget arbeider vi som tenkende, handlende og følende mennesker. «Mentalisering er en form for følelsesmessig kunnskap som bidrar til følelsesregulering og mestring» (Skårderud \& Duesund, 2014, s. 153).

Mentaliseringsbegrepet kan i denne sammenheng knyttes til Berthold Brechts verfremdungsbegrep - underliggjøring eller distansering. Verfremdung handler i et teatervitenskapelig perspektiv om å anvende ulike strategier og virkemidler for å «vekke publikum til ettertanke og diskusjon» (Gladsø et. al., 2015, s. 130). А overføre Brechts krav til verfremdung til dramapedagogikken handler blant annet om at dramapedagogen må forholde seg til virkeligheten på alle områder og lære deltagerne til å utforske, analysere og kritisere deres egen virkelighet på en grundig måte (Braanaas, 2002, s. 125). Knyttet til distanseperspektivet beskriver Eriksson (2011) et konsept som har en viktig posisjon i dramafaget, nemlig beskyttelse fra virkeligheten. Eriksson poengterer at de temaer som blir utforsket i fiksjonen kan oppleves som mindre truende når vi har en distanse til det virkelige liv (Eriksson, 2011, s. 65-66).

\section{Funn og diskusjon}

Gjennom den tematiske analysen av datamaterialet har vi konstruert tre hovedtemaer: kroppens minne, gjenkjennelsesfelleskapet og distanseperspektivet. Gjennom disse temaene settes søkelyset på hvordan performativ kunstdidaktikk kan åpne opp for en helhetlig refleksjon over praksiserfaringer.

\section{Kroppens minne - «det har blitt min rute, min lille dans»}

Flere studenter sier at de oppdager andre elementer ved en erfaring enn ved den tradisjonelle skriftlige rapporten, når de jobber kunstdidaktisk. Noen påpeker at praksiserfaringen kan være sårbar.

Når du gjør bevegelser så får du en følelse. Hvis du står veldig åpent så kjenner du på sårbarheten og det det innebærer å åpne seg opp og stå i det. (Informant 1)

Ved å arbeide performativt og kunstdidaktisk med praksiserfaringen, kommer sårbarheten til syne. Intellektet iverksettes i dramaarbeidet sammen med følelsesregisteret. En erfaring innebærer også følelser, noe som kan innebære å vise seg sårbar. Å dele sårbarhet med hverandre handler om å ha tillit til hverandre. I forbindelse med forløpet fra praksiserfaring til bevegelses presentasjon, uttrykte en student at gjennom dette arbeidet oppdaget hen også de sårbare erfaringene fra praksis.

Nå turte jeg å velge en bevegelse som var sårbar og kunne liksom se litt på praksisen på en ny måte, en ny inngang. (Informant 2) 
Studentens kommentar tolker vi som at hen opplevde at den kroppslige erfaringen åpnet opp for en ny erkjennelse, som innebar å vedkjenne seg egne følelser og sårbarhet. Ved å iverksette kroppens minne gjennom den kunstdidaktiske praksisrefleksjonen, erfarer flere studenter at de åpner opp for sitt følelsesregister. «Bevegelse, tenkning, affekter og følelser forstås i teori om kroppslig læring som parallelle aktiviteter. Dermed aktiveres både tanker, affekter og følelser idet et menneske tar del i kroppslig læreprosesser» (Østern et al., 2019, s. 50). I dramaarbeidet kan ikke studentene "gjemme" seg bak skriftlige ord. Kroppens bevegelser igangsetter, ifølge studentene, følelser som man ikke nødvendigvis fokuserer på i en skriftlig rapport i en praksisgruppe. Etter å ha uttrykt praksiserfaringer gjennom bevegelses-improvisasjoner (kunstdidaktisk forløp 3), beskriver en student opplevelsen slik:

Det som ble litt tydelig, sånn følelsesmessig, var når du er i undervisningssituasjon du gir skikkelig $100 \%$, og er full av energi og etterpå - hvor utkjørt du er. Følelsen av å være helt utkjørt. Da kommer alle følelsene og frustrasjonene som du ikke kunne vise i undervisningstimen. Liksom den forskjellen ble veldig tydelig når vi jobba nå. (Informant 5)

Videre reflekterer og poengterer flere studenter at arbeidet med bevegelsesimprovisasjon som praksisrefleksjon i forløp nr. 3 tilførte en mer fri tilgang til refleksjonene. I skriftlige praksisrapporter, muntlige presentasjoner og mer tradisjonell klasseromsrefleksjon opplever studentene ikke like stort rom for den emosjonelle delen av en erfaring. Ifølge Dewey (1934) er det det emosjonelle som binder delene (intellektuell, praktisk og følelsesmessig) av en erfaring sammen (Dewey, 1934, s. 211). Gjennom det kunstdidaktiske arbeidet sier flere studenter at de våget å gå inn i andre erfaringer enn de ville giort i skriftlige rapporter og muntlige fremlegg. Slik vi tolker det, skaper det kunstdidaktiske arbeidet et refleksjonsrom hvor en erfaring ikke er mer 'riktig' enn en annen. Gjennom det kunstdidaktiske arbeidet får studenten mulighet til å skape sin egen erfaring. Ifølge Dewey må skaperaktiviteten knyttes til opphavsmannen selv gjennom en organiseringsprosess (Dewey, 1934, s. 211). Ved å utføre denne organiseringsprosessen giennom kunstdidaktisk arbeid og gjenskapende handling aktiveres mangfoldet av kroppens emosjonelle minner. Studenten under beskriver hvordan hen gjennom arbeidet også fikk mulighet til å fokusere på de positive erfaringene gjennom det kunstdidaktiske arbeidet:

Når man er satt i en skriftlig refleksjonssituasjon da er det veldig naturlig for meg å gå rett til det negative. Jeg tenker da bare over de kjipe situasjonene og ting jeg kunne gjort annerledes. [...] Det er jo ikke det jeg husker best egentlig! Det jeg husker best er de fine øyeblikkene og den varmen du føler, hvor glad du blir i dem og ... hvor gøy vi har hatt det. (Informant 7)

Praksisrefleksjonen handler også om å bli bevisst de gode øyeblikkene. Dette handler om å utdanne lærere som evner å balansere mellom utfordringer og muligheter. Noe av essensen vi finner i studentens refleksjoner er at de gjennom det kunstdidaktiske arbeidet utvider tolkningsrommet av sine praksiserfaringer. Utredningen Fremtidens 


\section{S. N. Ellinggard $\mathcal{E}$ K. B. Bjerkestrand}

skole fremhever at "sosial og emosjonell kompetanse» står sentralt i alle fire hovedkompetansene til fremtidens lærer (NOU 2015: 8). Utredningen definerer "sosial og emosjonell kompetanse» som en persons holdninger, oppførsel, emosjoner og sosiale ferdigheter og relasjoner (Sæbø, 2016, s. 72-73). En student påpeker at arbeidet hjalp til med å rydde opp i egne emosjoner knyttet til det å være lærer. Studenten refererer til forløpet, hvor hen fikk være publikum til iscenesettelse av sin egen praksisfortelling (kunstdidaktisk forløp 2).

Det er jo situasjoner som oppstår som du kanskje ikke har lyst til å grave i. Men nå får man liksom muligheten til å rydde opp i egne følelser med bare seg selv. (Informant 10)

Studentens utsagn tolker vi som at gjennom et kunstdidaktisk refleksjonsarbeid kan studentene utvide et uttrykksrepertoar ved bruk av kroppen som fortolkningsverktøy. Studenten kan gjennom arbeidet øve på å kjenne seg selv innenfra for å forstå andre utenfra. En lærer som kjenner seg selv følelsesmessig er kanskje bedre rustet i møte med elever og situasjoner som kan utfordre læreren? Mentalisering kan på så måte hjelpe læreren til å møte eleven på en profesjonell måte og ikke la følelser/reaksjoner som sinne og frustrasjon ta overhånd. Sosial kompetanse er helt essensiell for å bygge gode læringsmiljø og skape gode relasjoner. Mentalisering «er grunnlaget for god kommunikasjon, sunne forhold, delte verdier og følelsene av fellesskap» (Skårderud \& Duesund, 2014, s. 153).

Etter å ha gjennomført forløpet Fra praksiserfaring til bevegelses presentasjon (kunstdidaktisk forløp 1), hadde en student følgende refleksjon:

Det var veldig deilig å gi uttrykk for hvordan du egentlig har opplevd praksis uten å bruke ord. Bare det å få lov å fortelle. Var så godt. En oppdagelse jeg gjorde er at nå føler jeg at min praksis er komplett ... for nå har jeg fått lov til å fortelle min side av det. Det har blitt ... min rute og min lille dans. (Informant 7)

Ved å aktivt ta i bruk kroppens minne som verktøy i studentenes praksisrefleksjon, ser vi at det kan åpne opp for et utvidet tolkningsrom. Som lærere ber vi ikke studentene om å tenke over, men vi ber dem om å lagelforme/utvikle bevegelser som kan si noe om en følelse man har av en erfaring. Flere studenter var opptatt av at det å jobbe med bevegelser i en kunstdidaktisk kontekst også inkluderer den emosjonelle delen ved praksisrefleksjonen. De opplever, slik vi tolker det, at de blir bevisst egen erfaring på en annen måte gjennom denne tilnærmingen. Bogart og Landau (2005) er opptatt av forskjellen mellom deskriptiv og ekspressiv iscenesettelse $i$ arbeidet med viewpoints. Når vi jobber ekspressivt, handler det om hvordan noe føles. Det deskriptive handler om hvordan noe nøyaktig skjedde. For å forklare valget av å jobbe med ekspressive uttrykksformer, henviser Bogart og Landau til kunstneren Constantin Brancusi:

When you see a fish, you do not think of its scales, do you? You think of its speed, its floating, flashing body seen through water. Well, I've tried to express just that. If I made fins and eyes and scales, I would arrest its movement and hold you by a pattern, or a shape of reality. I want just the flash of its spirit. (Bogart \& Landau, 2005, s. 146) 
Ved å jobbe ekspressivt sier flere studenter at de får et genuint og mangfoldig eierskap til sin egen praksiserfaring og praksisrefleksjon.

Gjenkjennelsesfelleskapet - «jeg ble bevisst sider jeg kanskje ikke har tenkt over før» Studentene gir uttrykk for at det å dele erfaringer og gjenkjenne egne erfaringer hos andre skaper et gjenkjennelsesfellesskap. Ved å etablere en delingskultur, kan den individuelle praksiserfaringen bli anerkjent. I forløpet Fra praksiserfaring til fortelling $i$ rolle med bevegelsesimprovisasjon (kunstdidaktisk forløp 2) fikk studentene mulighet til både å fortelle sin egen praksisfortelling og være publikum til medstudentenes iscenesettelse av den. De kunne dermed oppleve sin egen fortelling gjennom de andres presentasjon av den, slik denne studenten uttrykker:

Jeg kjente meg litt ensom. Åhh ... herregud dette går ikke, jeg kan ikke det. Man lever så i sin egen boble. Det er derfor det er så fint med å gjenkjenne seg selv i andre. (Informant 3)

Slik vi tolker det, ble det viktig for denne studenten at det å dele og gjenkjenne kan skape et erfaringsfellesskap. Flere studenter påpeker at de gjennom å være både deltager og publikum fører til at de gjenkjenner det som utspiller seg. Dette kan, slik vi tolker det, utvide en bevissthet om refleksjon omkring egen virkelighet. Denne prosessen kan vi knytte opp mot Aristoteles omslag fra uvitenhet til viten (Aristoteles, 1997, s. 46).

Gjennom å gjenkjenne kan vi bli en del av et fellesskap og erfaringen kan få en større verdi, slik denne studenten beskriver etter å ha vært tilskuer i kunstdidaktisk forløp 3 (Fra praksiserfaring til bevegelsesimprovisasjon):

Når det gjelder det å kjenne seg igjen $i$ ting så er det en sånn veldig menneskelig ting. Hvis det er noe du opplever som er kjipt, så er det kjempedeilig å høre om andre som også har det kiipt. [...] Det er godt å høre at noen andre har strevd med samme type ting. At man ikke tenker at det bare går på deg. (Informant 6)

Ifølge denne studenten handler det å gjenkjenne, slik vi tolker det, om å komme på nye opplevelser når man gjenkjenner erfaringer hos andre. Dette kan knyttes til Erika Fisher-Lichtes teaterforståelse om teater som en sosial hendelse, hvor hun hevder at det kan skapes en refortryllende grenseerfaring, der publikum kan oppleve seg selv i en ny relasion til verden (Fisher-Lichte, 2008, referert i Larsen, 2019, s. 6). Flere studenter gav uttrykk for at det å få være publikum til andres iscenesettelser av praksiserfaringene gav dem nye tanker, assosiasjoner og bilder av seg selv som lærer. Kanskje opplevde de seg selv i en ny relasjon til verden? Denne assosieringsprosessen kan være med på å ufarliggiøre og skape et trygt rom hvor studentene kan dele sårbare temaer fra praksis. Dette kan igjen gjøre studentene til tryggere lærere giennom en utvikling av lærerrollens følelsesmessige kunnskap (Skårderud \& Duesund, 2014). En slik utvikling blir beskrevet av en student, etter å ha vært publikum til gruppens fortelling og bevegelsesimprovisasjoner (kunstdidaktisk forløp 2): 
Jeg ble bevisst sider jeg kanskje ikke har tenkt over før. For eksempel behovet for å fremstå standhaftig og trygg, siden resten av gruppa viste frykt og nerver. Jeg ble bevisst at jeg har kjent meg dratt mellom to parter til tider. Jeg synes det var litt spennende i visningene fordi jeg føler på en måte at det jeg så i de andres bevegelser kanskje reflekterer egne opplevelser også. (Informant 7)

Her ser vi hvordan gjenkjennelsesfelleskapet kan bidra som en form for anerkjennelse av egne erfaringer. Handlinger i et fiktivt dramaforløp kan være utforskende og fortolkende i lys av det handlingene er et speil av, nemlig deltakernes egne virkelighetsbilder (Haugsted, 1996b, s. 109).

Jeg tenker på at når man gjenkjenner og ser at resten av gruppa gjør det, så åpner det jo veldig opp for å prate om det man kjente seg igjen i. Det er en veldig fin måte å åpne opp for å dele erfaringer. [...] Det er en fin inngang. (Informant 12)

Flere studenter uttrykker at de setter pris på vekselvirkningen mellom individuell kunstdidaktisk refleksjon og gjenkjennelsesfellesskapet. Ifølge Dewey (1934) er gjenkjennelse persepsjon. Skal vi forstå dette gjennom Deweys perspektiver, kan vi ta et kritisk blikk på gjenkjennelse som et isolert startpunkt for refleksjon. «Gjenkjennelse er altfor lettvint til å vekke bevisstheten. Det er ikke nok motstand mellom nytt og gammelt til at bevisstheten tar til seg den erfaringen den har hatt» (Dewey, 1934, s. 210). Det vil derfor være betydningsfullt å etterstrebe at gjenkjennelsesfellesskapet står i samspill med kroppens minne, deltakeren selv og distanseperspektivet.

\section{Distanseperspektivet - «jeg kom i kontakt med kroppens erfaring av praksis»}

Det fremgår av datamaterialet at studentene gjennom arbeidet opplever kombinasjonen av analytisk og formmessig virksomhet som svært meningsfull. Gjennom fiksjonen skapes det en distanse til det alvorlige. Dette handler om å abstrahere en opplevelse - slik at det blir håndgripelig å reflektere over. Dette kan knyttes til Erikssons (2011) beskrivelse av distanseperspektivet som gir beskyttelse gjennom fiksjonen. Denne bevisstgjøringen kan for mange oppleves som frigiørende, slik denne studenten beskriver:

Bare en oppfølging ... det å legge lokk på. Når jeg kjente på kroppen hvor mye jeg egentlig la lokk på. Man er så opptatt av at det er praksisperiode. Alle skal få godt inntrykk. Jeg slipper ikke til alle de vanskelige følelsene. Jeg måtte ha kontroll nå var det trygt på en måte ... Det var så deilig å bare slippe ut. (Informant 7)

Flere studenter kommenterte også at fiksjonsvernet virket beskyttende og at det skapte rom for å oppdage nye sider ved en erfaring. Haugsted (1996b) poengterer at ved å lære gjennom kunstformen drama, åpner vi opp for noe annet enn gjennom den tradisjonelle samtalen og diskusjonen: "Den er udtrykt i og erfaret gennem aktiv handling $i$ en bestemt kunstnerisk form» (Haugsted, 1996b, s. 109). Dewey beskriver hvordan den erfaringsbaserte og den intellektuelle prosessen gjensidig påvirker hverandre: «Den ene prosessen er en ytre fysisk prosess hvor hendene begriper et materiale; den andre er en indre prosess hvor man begriper noe nytt» (Dewey referert i Fredriksen, 2013, s. 30). 
En student beskriver samspillet mellom en indre og ytre prosess av en erfaring. Etter å ha delt og opplevd sin praksisfortelling gjennom fortelling $i$ rolle med bevegelsesimprovisasjon (kunstdidaktisk forløp 2), uttrykte studenten følgende:

Jeg fikk en åpenbaring over hvilken rolle jeg tok i gruppa. Når er du i og utenfor? Vi var en veldig ærlig gruppe med hverandre ... sa alt vi følte. Men i ettertid ser jeg jo at det er noen roller du tar for å kompensere andre. Jeg var veldig trygg utad, men inni meg var jeg ikke det. Det er mange ting du gjør utad som du ikke nødvendigvis føler. Forskjell på valg og følelser inni meg. (Informant 11)

Denne studentens refleksjon kan forstås som at hen hadde en indre dialog med seg selv hvor kroppen og intellektet samspiller og utforsker ulike praksiserfaringer. Samtidig påpeker studenten at dette arbeidet også tilfører en bevissthet og refleksjon over lærerkroppen og hvordan den kan virke i en klasse. Det betyr at det skjer flere prosesser samtidig - man bearbeider en erfaring, samtidig som man oppdager nye sider ved det å utvikle lærerrollen.

En annen student utdyper dette etter arbeidet med Fra praksiserfaring til fortelling $i$ rolle med bevegelsesimprovisasjon (kunstdidaktisk forløp 2):

Å jobbe på denne måten her kan kanskje hjelpe deg med å bli mer bevisst hvordan du selv fremstår når du giør ulike gester i klasserommet. Hvordan elevene kanskje oppfatter det. [...] en bevisstgjøring på holdning, gester og utrykk og sånn. (Informant 13)

Slik vi tolker det, er studentene opptatt av at de giennom den performative kunstdidaktikken får en arena hvor de gjennomgår en ny bevisstgjøring av en erfaring. Dewey (1934) skriver at vi så altfor ofte haster av sted til nye oppgaver, og at våre erfaringer ofte blir flyktige og ikke fullførte. Å fullføre en erfaring handler i denne sammenheng om å koble seg på både emosjonelt, estetisk og intellektuelt. Denne prosessen handler om å anerkjenne motstand som en "invitasjon til ettertanke» (Dewey, 1934, s. 204).

I det kunstdidaktiske arbeidet skapes det rammer studentene skal arbeide innenfor. All fiktiv handling har en slags ramme; noen regler som setter rammer for de subjektive uttrykk - eller rettere sagt de estetiske formede uttrykk. Spillet (den estetiske erfaringen) gir mulighet for å danne og avprøve (personlig) identitet i en estetisk ramme oftest i et fellesskap med andre - som tilsvarende eksperimenterer (Haugsted, 1996b, s. 13). I denne dialogiske bevegelsen forekommer et samspill mellom subjekt, objekt og meningshelhet.Vi kan få kunnskap om hva vi giør delvis gjennom at vi kan objektivere våre handlinger for å konfronteres med dem. Det åpnes opp for muligheten til å skifte perspektiver og posisjoner ved å gå inn og ut av ulike roller.

Theatre and drama in education is based on the assumption that in learning process it can be advantage to be aware of shifting knowledge positions, to be able to perform different roles, as well as being able to include and perceive various perspectives. (Knudsen \& Krøgholt, 2019, s. 41-42)

Når det teatermessige formspråket er i fokus som rom for personlige og felles uttrykk, opplever flere studenter viktigheten av å anerkjenne også det 'uperfekte'. Basert på 
erfaringen med å uttrykke praksiserfaring gjennom bevegelsesimprovisasjon, beskrev en student følgende:

Det var en gave å få sitte å se på andres opplevelse, og det ble så sårbart og nært. Man fikk så mye respekt for de som står der fremme og viser en uperfekt vei mot et mål. Det er så sjelden vi anerkjenner usikkerhet. Jeg kom i kontakt med kroppens erfaring av praksis. (Informant 9)

Vi opplever at studentene verdsetter kombinasjonen av å 'skue spillet' og 'spille noe til skue’. Når de skuer spillet er de aktiviserte og påkoblet som publikum. På den måten blir de også medskapere i den individuelle refleksjonen. Når du er bevisst det 'uperfekte' i deg selv, og forstår deg selv, dine følelser og reaksjoner, er du mer styrket i møte med lærerrollen, andre mennesker og elever.

\section{Oppsummering og avsluttende refleksjoner}

Gjennom denne studien har vi generert tre hovedtemaer som er sentrale i undersøkelsen om hva performative kunstdidaktiske erfaringer kan tilføre praksisrefleksjonen til PPU-studenter i drama og teater. Tre perspektiver vokste frem gjennom analysen av datamaterialet: kroppens minne, gjenkjennelsesfellesskapet og distanseperspektivet. Dramafagets performative kunstdidaktiske tilnærming tilbyr et utvidet refleksjons- og tolkningsrom over praksis og egen lærerrolle. Praksiserfaringene inkluderer sanseerfaringer og disse kommer til uttrykk gjennom en performativ tilnærming. Her åpnes det opp for refleksjoner over opplevelser og følelser i en kollektiv utforskende prosess.

Studentene poengterer at de gjennom den performative kunstdidaktiske praksisrefleksjonen blir mer bevisst de emosjonelle opplevelsene fra praksis. De opplever det som viktig å få bearbeide disse følelsene. Dette handler om å forene det praktiske, følelsesmessige og intellektuelle (Dewey, 1934, s. 211). Basert på tolkning av studentenes erfaringer og refleksjoner, vil vi hevde at den estetiske erfaringen åpner opp for en fornyet bevissthet om egen lærerrolle basert på handlende og sanselig fortolkning. På denne måten tilfører den kunstdidaktiske praksisrefleksjonen også en utvikling av den følelsesmessige kunnskapen, noe som kan bidra til følelsesregulering og mestring i rollen som lærer (Skårderud \& Duesund, 2014).

Med en forankring i PPU-feltet er vi opptatt av studiens relevans også i et mer overordnet lærerutdanningsperspektiv. Fagfornyelsen er i høyeste grad aktuell for lærerstudenten. Dette handler ikke kun om et innholdsmessig faglig fokus, men også om lærerstudentens relasjonelle ferdigheter og metodekompetanse. Ifølge regjeringens strategi Skaperglede, engasjement og utforskertrang, fremheves det at "praktiske og estetiske fag er spesielt egnet til å etablere god klasseledelse og skape gode læringsprosesser. De praktiske og estetiske fagene gir en praktisk og kroppslig tilnærming til begrepslæring og forståelse» (Kunnskapsdepartementet, 2019, s. 10). Drama er ikke et eget fag i skolen, men et skolerelevant fag. Læreren skal ha relasjonell kompetanse, evne til å utvikle seg og kunne bruke varierte undervisningsmetoder. Vi ser, gjennom 
denne studien, at performativ kunstdidaktisk praksisrefleksjon, som tar i bruk dramadidaktiske metoder, kan styrke lærerstudenters relasjonelle kompetanse.

Fremtidens skole trenger lærere som er endringsvillige, kan mestre utfordringer og som har relasjonell kompetanse. Performativ kunstdidaktisk praksisrefleksjon kan bidra til et utvidet refleksjonsrom og en økt bevissthet om egne muligheter, utfordringer og kompetanser i utviklingen av lærerrollen.

\section{Forfatteromtale}

Stine N. Ellinggard er universitetslektor ved OsloMet - storbyuniversitet, Institutt for estetiske fag. Hun underviser i drama- og teaterkommunikasjon og PPU, og arbeider med dramadidaktikk inn i skoleutvikling. Hennes forskningsområder er blant annet anvendt teater, etnoteater, dramapedagogikk og fysisk teater.

Karin B. Bjerkestrand er førstelektor i drama og teater ved Universitetet i Stavanger. Hun underviser blant annet på PPU og drama i lærerutdanningen ved UiS. Hun arbeider med anvendt teaterforskning og dramapedagogikk, samt utvikling av forumteater i et mangfoldsperspektiv.

\section{Referanser}

Aristoteles. (1999). Den nikomakiske etikk. Bokklubbens dagens bøker.

Aristoteles. (1997). Om diktekunsten. Grøndahl og Dreyer.

Aure, V. (2013) Didaktikk - i spennet mellom klassisk formidling og performativ praksis. Nordic fournal of Art and Research, 2(1), 1-24. https://doi.org/10.7577/if.v2i1.611

Bogart, A. \& Landau, T. (2005). The viewpoints book: A practical guide to viewpoints and composition. Theatre Communications Group.

Braanaas, N. (2002). Dramapedagogisk historie og teori. (4. utg.).Tapir Forlag.

Braun, V. \& Clarke, V. (2006). Using thematic analysis in psychology. Qualitative Research in Psychology, 3(2), 77-101. https://doi.org/10.1191/1478088706qp063oa

Dewey, J. (1934). Å gjøre en erfaring. I K. Bale. \& A. Bø-Rygg (Red.), (2008), Estetisk teori: En antologi. (s. 194-213). Universitetsforlaget.

Eriksson, A. S., (2011). Distancing. I S. Schönmann (Red.), Key concepts in theatre/drama education. (s. 65-70). Sense Publisher.

Fischer-Lichte, E. (2008). The transformative power of performance. A new aestethics. Routledge.

Forskrift om rammeplan for PPU. (2015). Forskrift om rammeplan for praktisk-pedagogisk utdanning (FOR-201512-21-1771). Lovdata. https://lovdata.no/dokument/SF/forskrift/2015-12-21-1771

Fredriksen, B. C. (2013). A begripe med kroppen. Barns erfaringer som grunnlag for all lcering. Universitetsforlaget.

Gadamer, H. G. (2010). Sannhet og metode. Grunntrekk $i$ en filosofisk hermeneutikk. Pax Forlag.

Gladsø, S., Gjervang K. E., Hovik, L. \& Skagen, S. (2015). Dramaturgi. Forestillinger om teater. Universitetsforlaget.

Haugsted, M. T. (1996a). Drama et kunst og erkjennelsesfag. KVAN - et tidsskrift for larerutdannelsen og folkeskolen, (16), 7-18.

Haugsted, M. T. (1996b). Sprog på spil handlende muntlighed og drama. Dansklærerforeningen.

Heggstad, K. M., Eriksson, S. A. \& Rasmussen, B. (2013). Redaktørenes introduksjon. I K. M. Heggstad, S. A. Eriksson \& B. Rasmussen (Red.), Teater som danning (s. 11-20). Fagbokforlaget.

Knudsen, K. N. \& Krøgholt, I. (2019). Revitalizing drama in education through fictionalization. I A.-L.Østern \& K. N. Knudsen (Red.), Performative approaches in arts education: Artful teaching, learning, and research (s. 38-55). Routledge. 


\section{S. N. Ellinggard E K. B. Bjerkestrand}

Kunnskapsdepartementet. (2019). Skaperglede, engasjement og utforskertrang. Praktisk og estetisk innhold $i$ barnehage, skole og larerutdanning. https://www.regjeringen.no/no/dokumenter/skaperglede-engasjement-og-utforskertrang/id2665820/

Kvale, S. \& Brinkmann, S. (2015). Det kvalitative forskningsintervju. Gyldendal Norsk Forlag.

Larsen, W. (2019). Likestilt dramaturgi. Teatervitenskapelige studier, (3), 39-54. https://doi.org/10.15845/tvs. v3i0.2927

NOU 2015: 8. (2015). Fremtidens skole. Fornyelse av fag og kompetanser. https:/www.regjeringen.no/no/ dokumenter/nou-2015-8/id2417001/

Rasmussen, B. (2013). Teater som danning - i pragmatisk-estetiske ramme. I K. M. Heggstad, S. A. Eriksson \& B. Rasmussen (Red.), Teater som danning. (s. 21-34). Fagbokforlaget.

Skårderud, F. \& Duesund, L. (2014). Mentalisering og uro. Norsk pedagogisk tidsskrift, 98(3), $152-164$.

Szatkowski, J. (1996). Åpen prøve. KVAN - et tidsskrift for lererutdannelsen og folkeskolen, (16), 16-44.

Sæbø, A. B. (2016). Drama som laringsform. Universitetsforlaget.

Østern, T. P., Dahl, P., Strømme, A., Petersen, J. Aa., Østern, A.-L. \& Selander, S. (2019). Dybde//lering - en flerfaglig, relasjonell og skapende tilncerming. Universitetsforlaget.

Østern A.-L. \& Knudsen, N. K. (2019). Performative approaches in arts education: Artful teaching, learning, and research. Routledge. 